\title{
Diagnostic Role of Parotid Computed Tomography for Identifying Sjögren's Syndrome
}

\author{
Hyung Sun Hong, ${ }^{1}$ Hong-Ju Kim ${ }^{1}$, Soo Hyun Joo ${ }^{1}$, Young-Hye Kang ${ }^{2}$, \\ Mie Jin Lim ${ }^{3}$, Jeong-Seok Choi ${ }^{1}$, Young-Mo Kim ${ }^{1}$, and Ji Won Kim ${ }^{1}$ iD \\ ${ }^{1}$ Departments of Otorhinolaryngology-Head and Neck Surgery, ${ }^{2}$ Radiology, ${ }^{3}$ Internal medicine, Inha University College of Medicine, \\ Incheon, Korea
}

\section{쇼그렌 증후군 진단에서 이하선 전산화단층촬영의 유용성 \\ 홍형선 ${ }^{1} \cdot$ 김홍주 $^{1} \cdot$ 주수현 $^{1} \cdot$ 강영혜 $^{2} \cdot$ 임미진 $^{3} \cdot$ 최정석 $^{1} \cdot$ 김영모 $^{1} \cdot$ 김지원 $^{1}$ \\ 인하대학교 의과대학 이비인후-두경부외과학교실, ${ }^{1}$ 영상의학과학교실, ${ }^{2}$ 내과학교실 ${ }^{3}$}

\author{
Received May 24, 2019 \\ Revised August 23, 2019 \\ Accepted August 28, 2019 \\ Address for correspondence \\ Ji Won Kim, MD \\ Department of Otorhinolaryngology- \\ Head and Neck Surgery, \\ Inha University College of Medicine, \\ 27 Inhang-ro, Jung-gu, \\ Incheon 22332, Korea \\ Tel $+82-32-890-2817$ \\ Fax $+82-32-890-3580$ \\ E-mail hopefuljw@gmail.com
}

Background and Objectives Sjögren's syndrome (SS) is an autoimmune inflammatory disorder of exocrine glands characterized by dry mouth and eye. Recently, ultrasonography has become a valuable tool for the assessment of salivary gland involvement in SS although studies on the usefulness of salivary gland CT is rare. In this regard, we evaluated the diagnostic accuracy of parotid gland CT for SS.

Subjects and Method A total of 91 patients with sicca symptoms took a parotid CT, a serology test, an ophthalmologic examination and a minor salivary gland biopsy. At the end, as a standard, we diagnosed the primary SS according to the new 2016 American College of Rheumatology/European League Against Rheumatism classification criteria. The diagnostic value of parotid CT was compared by the McNemar test.

Results Of the total of 91 patients with parotid CT, 37 (40.7\%) patients met the SS classification criteria. On the parotid CT, heterogeneity of the parotid gland has the sensitivity of $74.1 \%$, specificity of $70.3 \%$, and accuracy of $71.4 \%$. The abnormal fat tissue deposition showed the sensitivity of $74.1 \%$, specificity of $81.3 \%$, and accuracy of $79.1 \%$. Diffuse calcification was seen in 1/91 SS patients (sensitivity $3.7 \%$, specificity $100 \%$, accuracy $71.4 \%$ ).

Conclusion Parotid CT is helpful for the diagnosis of SS. The presence of heterogeneity and fat tissue deposition are highly sensitive for the accuracy of SS. Diffuse calcification in bilateral parotid glands is highly specific for SS.

Korean J Otorhinolaryngol-Head Neck Surg 2020;63(8):369-74

Key Words Computed tomography, X-ray · Diagnosis $\cdot$ Sjögren's syndrome $\cdot$ Parotid gland.

\section{서 론}

쇼그렌 증후군(Sjögren's syndrome, SS)은 타액선과 눈물 샘 등의 외분비샘의 림프구 침윤을 특징으로 하는 류마티스 성 자가 면역 질환으로 각성 결막염과 건조증을 유발할 뿐만

This is an Open Access article distributed under the terms of the Creative Commons Attribution Non-Commercial License (https://creativecommons.org/licenses/by-nc/4.0) which permits unrestricted non-commercial use, distribution, and reproduction in any medium, provided the original work is properly cited.
아니라 관절통, 관절염 등의 증상과 피부, 폐, 신장 혹은 신경 계 증상 등의 샘외 증상(extra-glandular manifestations)을 일으키기도 한다. ${ }^{1)}$ 쇼그렌 증후군의 진단으로는 2002년 미 국-유럽 합의그룹(American-European Consensus Group, $\mathrm{AECG)}$ 에서 발표한 쇼그렌 증후군 분류기준이 가장 보편적 으로 사용되는데, 여기엔 타액선과 눈물샘의 주관적, 객관적 증상과 소타액선 조직 검사의 병리학적 소견, 항-SSA/Ro, 항-SSB/La등의 항목이 포함된다. ${ }^{2}$ 이후 2012년 미국 류마티 
스학회(American College of Rheumatology, ACR)에서 새로 운 분류기준을 발표하였는데, 여기엔 안구 염색 점수(ocular staining score)와 림프구성 침샘염(lymphocytic sialadenitis) 이 포함되어 좀 더 객관적인 기준을 강화하였다. ${ }^{3)}$ 2016년 ACR/European League Against Rheumatism(EULAR)에서 발표한 분류기준은 실제 임상에서 적용이 용이하도록 쉽게 시 행할 수 있고, 객관적인 기준들로 구성되었다. ${ }^{4}$

지금까지 발표된 쇼그렌 증후군의 분류기준에는 영상의학 적 검사가 진단기준으로 포함된 적이 없었으며, 최근 초음파가 쇼그렌 증후군의 진단에 도움이 된다는 연구가 있었으나, ${ }^{5-7)}$ 이하선 전산화단층촬영의 쇼그렌 증후군 진단에의 유용성에 대한 연구는 거의 없어 그 유용성이 정립되지 않았다. ${ }^{89}$ )

본 연구에서는 쇼그렌 증후군이 의심되는 환자를 대상으 로 이를 진단함에 있어 이하선 전산화단층촬영의 진단적 유 용성에 대해 정보를 제공하고자 한다.

\section{대상 및 방법}

\section{대 상}

본 연구는 2012년 1월 2018년 12월까지 눈마름이나 입마 름으로 인하대병원을 내원한 환자로 쇼그렌 증후군이 의심 되는 환자 중 다른 이유(경부에 만져지는 덩이나 경부 림프 절 종대, 부비동염, 갑상선 질환 등)로 전산화단층촬영을 시 행한 환자들을 대상으로 하였다. 두경부에 방사선 조사를 받 은 적이 있거나, 방사성 요오드 치료를 받은 적이 있는 환자 는 배제되었으며, 입마름을 유발할 수 있는 약제 ${ }^{10)}$ (항우울제, 항정신병약, 항콜린제, 항고혈압제, 항히스타민제, 진정제 등) 를 복용한 환자들도 대상에서 제외되었다. 대상 환자에서 상 세한 문진과 설문을 통해 병력을 청취하였고, 이하선 전산화 단층촬영, 혈청학적 검사, 안과학적 검사 그리고 소타액선 침 샘 조직 검사를 시행하였다. 본 연구는 의료기록을 검토하여 후향적 연구로 진행되었으며, 인하대학교병원 Institutional Review Board(INHUH 2019-03-020-002)의 승인을 얻었 고 절차를 준수하였다.

\section{방 법}

입마름, 눈마름의 주관적 증상을 호소하는 대상 환자들은 혈청학적 검사[항-Ro/SSA(62명), 항-La/SSB(58명), 류마티스 인자(65명), 항핵항체(76명)], 셔머 검사(52명), 비자극 타액속 도 검사(32명), 소타액선 조직 검사(11명)를 시행하였다. 검사 결과를 토대로 2016년 발표된 ACR/EULAR 쇼그렌 증후군 분류 기준 ${ }^{4}$ (Supplementary Table 1 in the online-only Data Supplement)에 따라 4점 이상인 경우 쇼그렌 증후군 그룹으
로 분류하였고, 진단기준에 부합하지 않은 군은 건조 증상 (non-Sjögren's sicca syndrome)군으로 구분하였다. 두 군에 서 혈청학적 검사(항-Ro/SSA, 항-La/SSB, 류마티스 인자, 학 행항체), 셔머 검사, 비자극 타액속도 검사, 소타액선 조직 검 사 및 이하선 전산화단층촬영 소견을 비교하였다.

이하선 전산화단층촬영 소견은 두경부 영상 판독의 20여 년의 경력이 있는 1 명의 영상의학과 전문의가 독립적으로 판 독하였으며, 1) 이하선의 균질성의 유무, 2) 광범위한 비정상 적 지방 조직 침착, 3) 광범위한 석회화 소견(Fig. 1)의 3가지 사항에 대해 분석하였다. ${ }^{9}$ 통계적 분석은 Windows용 SPSS 프로그램(Version 22.0, SPSS Inc., Armonk, NY, USA)을 사용하여 t 검정과 카이 제곱 검정 방법을 사용하였으며, 이 하선 전산화단층촬영의 민감도와 특이도에 대한 질적 기준 의 진단 유용성은 $\mathrm{McNemar}$ test로 평가하였다.

\section{결 과}

본 연구에 참여한 91 명의 대상자 중 남자는 15 명 여자는 76 명이었으며, 평균연령은 $59.08 \pm 12.80$ 세였다. 총 91 명의 대 상자 중 2016년 ACR/EULAR의 분류기준에 해당하여 쇼그 렌 증후군으로 분류되는 환자는 27 명이었고 진단기준에 부 합하지 않은 군은 64명으로 건조 증상군(non-Sjögren's sicca syndrome)으로 구분하였다. 두 그룹을 비교했을 때, 비자극 타액속도 검사는 건조 증상군에서 $0.26 \mathrm{~mL} / \mathrm{min}$, 쇼그렌 증 후군 그룹에서 $0.14 \mathrm{~mL} / \mathrm{min}$ 으로 나타났으며 $(p=0.026)$ 소타 액선 조직 검사상 focus score가 1점 이상인 림프구성 침샘염 (focal lymphocytic sialadenitis)을 보인 대상자는 건조 증상 군에서 6 명 중 1 명 $(16.7 \%)$, 쇼그렌 증후군 그룹에서 5 명 중 5명 $(100 \%)$ 으로 나타났다 $(p=0.013)$. 혈청학적 검사상 항-Ro/ $\mathrm{SSA}$ 검사에서 건조 증상군은 $25.7 \%$, 쇼그렌 증후군 그룹은 $88.9 \%$ 에서 양성을 보였으며 $(p<0.001)$, 항-La/SSA 검사에서 건조 증상군은 $12.9 \%$, 쇼그렌 증후군 그룹은 $51.9 \%$ 에서 양성 ( $p=0.002)$ 소견, 항핵항체 검사에서 건조 증상군은 $14.3 \%$, 쇼그렌 증후군군은 $48.1 \%$ 에서 양성 $(p=0.002)$, 류마티스인자 검사에서 건조 증상군은 $15.4 \%$, 쇼그렌 증후군 그룹은 $57.7 \%$ 에서 양성 $(p=0.001)$ 소견을 보였다. 이하선 전산화단층 촬영의 소견상 두 그룹에서 이하선의 균질성을 분석하였을 때 비균질성을 보인 환자수가 건조 증상군에서는 19 명 (29.7\%), 쇼그렌 증후군 그룹에서는 20명(74.1\%)으로 나타났 으며 $(p<0.001)$, 광범위한 비정상적 지방 조직 침착 소견을 보 인 환자는 건조 증상군에서 12 명(18.8\%), 쇼그렌 증후군 그 룹에서 20 명 $(74.1 \%)(p<0.001)$, 광범위한 석회화 소견을 보인 환자는 건조 증상군에서는 없었으며, 쇼그렌 증후군 그룹에 
Role of Parotid CT on Sjögren's Syndrome I Hong HS, et al.

Table1. Patients characteristics $(n=91)$

\begin{tabular}{|c|c|c|c|}
\hline Variable & Non-Sjögren's sicca syndrome $(n=64)$ & SS $(n=27)$ & p-value \\
\hline Age (years) & $60.17(13.10)$ & $56.62(11.89)$ & $0.215^{*}$ \\
\hline Sex, M:F & $13(20.3): 51(79.7)$ & $2(7.4): 25(92.6)$ & $0.215^{+}$ \\
\hline Salivary flow (unstim SFR) & $0.26(0.23)$ & $0.14(0.06)$ & $0.026^{*}$ \\
\hline \multicolumn{4}{|l|}{ CT finding } \\
\hline Heterogeneity of the parotid gland & $19(29.7)$ & $20(74.1)$ & $<0.001^{\dagger}$ \\
\hline Abnormal fat tissue deposition & $12(18.8)$ & $20(74.1)$ & $<0.001^{\dagger}$ \\
\hline Diffuse calcifications & $0(0)$ & $1(3.7)$ & $0.297^{\dagger}$ \\
\hline $\begin{array}{l}\text { Histopathology (FLS and focus score of } \geq 1 \text { foci } / 4 \mathrm{~mm}^{2} \text { ) } \\
\text { (positive/total) }\end{array}$ & $1 / 6(16.7)$ & $5 / 5(100)$ & $0.013^{+}$ \\
\hline Anti-Ro/SSA (positive/total) & $9 / 35(25.7)$ & $24 / 27(88.9)$ & $<0.001^{\dagger}$ \\
\hline Anti-La/SSA (positive/total) & $4 / 31(12.9)$ & $14 / 27(51.9)$ & $0.002^{+}$ \\
\hline ANA (positive/total) & $7 / 49(14.3)$ & $13 / 27(48.1)$ & $0.002^{\dagger}$ \\
\hline RF (positive/total) & $6 / 39(15.4)$ & $15 / 26(57.7)$ & $0.001^{\dagger}$ \\
\hline
\end{tabular}

Variables are presented as mean (standard deviation) or number (percentage). *Student † test, ${ }^{\dagger}$ chi- square test. SS: Sjögren's syndrome, Unstim SFR: unstimulated salivary flow rate, FLS: focal lymphocytic sialadenitis, ANA: anti nuclear antibody, RF: rheumatic factor

Table 2. Diagnostic accuracy of parotid CT for Sjögren's syndrome

\begin{tabular}{lrrrrccccc}
\hline \multicolumn{1}{c}{ Imaging } & TP & FP & FN & TN & Sensitivity (\%) & Specificity (\%) & Accuracy $(\%)$ & PPV (\%) & NPV (\%) \\
\hline Heterogeneity & 20 & 19 & 7 & 45 & $74.1(53.7-88.9)$ & $70.3(57.6-81.1)$ & $71.4(61.0-80.4)$ & $51.3(40.5-62.0)$ & $86.5(76.9-92.5)$ \\
Fat tissue deposition & 20 & 12 & 7 & 52 & $74.1(53.7-88.9)$ & $81.3(69.5-89.9)$ & $79.1(69.3-86.9)$ & $62.5(48.9-74.4)$ & $88.1(79.5-93.4)$ \\
Diffuse calcifications & 1 & 64 & 26 & 0 & $3.7(0.1-19.0)$ & $100(94.4-100.0)$ & $71.4(61.0-80.4)$ & 100 & $71.1(69.6-72.6)$ \\
\hline
\end{tabular}

TP: true positive, FP: false positive, FN: false negative, TN: true negative, PPV: positive predictive value, NPV: negative predictive value

서는 1명(3.7\%)( $p=0.297)$ 으로 나타났다(Table 1).

쇼그렌 증후군 진단에서의 이하선 전산화 단층촬영의 민감 도, 특이도, 정확도에 대한 분석에서는 이하선의 균질성을 기 준으로 하였을 때, 민감도 $74.1 \%$, 특이도 $70.3 \%$, 정확도 $71.4 \%(p<0.001)$, 광범위한 비정상적 지방 조직 침착 소견을 기준으로 하였을 때 민감도 $74.1 \%$, 특이도 $81.3 \%$, 정확도 $79.1 \%(p<0.001)$ 였다. 광범위한 석회화 소견을 보인 환자는 전 체 91 명의 환자 중 1 명으로 민감도 $3.7 \%$, 특이도 $100 \%$, 정확 도 $71.4 \%$ ( $p>0.05$ )를 보였다(Table 2).

전산화단층촬영의 결과와 쇼그렌 증후군 진단기준의 각 항목과의 연관성에 대한 분석에서는 건조 증상과 광범위한 비정상적 지방 조직 침착 소견이 유의한 상관관계를 보였고 $(p<0.05)$, 비균질성과 광범위한 비정상적 지방 조직 침착 소 견 모두 항-Ro/SSA, 항-La/SSA와 유의한 상관관계를 보였 다 $(p<0.05)$.

Receiver operating characteristic curve 곡선(ROC)을 통해 계산한 쇼그렌 증후군 진단에서의 이하선 전산화 단층촬영의 진단적 가치에 대한 분석에서는 이하선의 균질성을 기준으로 하였을 때 area under the curve(AUC)는 $0.722(p=0.001)$, 광범 위한 비정상적 지방 조직 침착소견을 기준으로 하였을 때 $\mathrm{AUC}$ 는 $0.777(p<0.001)$, 광범위한 석회화를 기준으로 하였을
때의 AUC는 0.519( $p=0.781)$ 로 계산되었다(Fig. 2).

\section{고 찰}

쇼그렌 증후군의 분류기준으로 가장 널리 쓰인 것은 2002년 $\mathrm{AECG}$ 분류기준이며, ${ }^{1)}$ 이 분류기준에는 주관적 건조 증상에 대한 설문과 함께 셔머 검사(Schirmer test), 비자극 타액 속 도 검사(unstimulated whole saliva flow rate), 이하선 타액 선 조영술(parotid sialography), 타액선 신티그래피 (salivary scintigraphy), 소타액선 조직 검사 등이 포함되었다. 영상학적 검사인 타액선 조영술은 검사자의 경험이 중요하고, 검사의 복잡성 때문에 자주 쓰이지 않는 검사이며, 신티그래피는 다 른 테스트에 비해 특이도가 낮다는 점과 방사선 노출의 단점 을 가지고 있다.11,12) 최근 쇼그렌 진단에 초음파 검사가 임상 적으로 이용되고 있고, 초음파의 유용성에 대한 연구가 활발 히 이루어지고 있으며,5) 초음파 소견이 소타액선 조직 검사의 조직학적 소견, 침샘 기능, 항-SSA/Ro 항체와의 연관성이 있 다고 보고되었다. 하하지만 침샘 초음파 역시 검사자 간의 해석 이 다양할 수 있다는 단점이 있다. 한편, 쇼그렌 증후군 환자 들은 자기공명영상 검사에서 지방 조직들은 균일하게 분포하 고, 낮은 감쇠를 보이는 특징이 있으며, 이하선 실질에 파괴가 

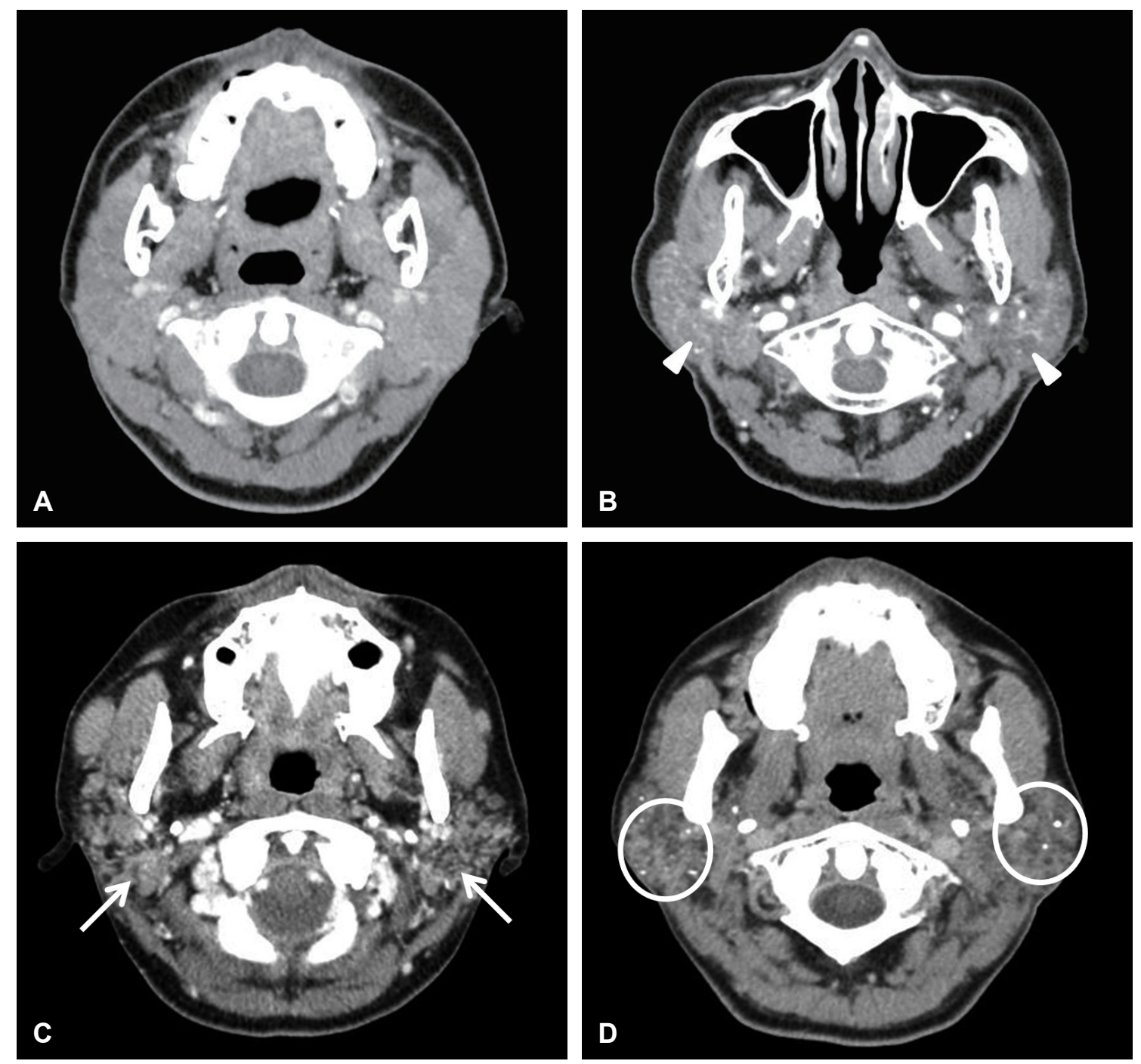

Fig. 1. Manifestations of parotid gland CT in Sjögren's syndrome. Normal parotid gland on CT (A). Heterogeneous parotid gland (B, arrowheads: ill-defined area with soft-tissue attenuation). Fat tissue deposition (C, arrows: the heterogeneous diffuse abnormal adipose tissue accumulation on parotid gland). Diffuse calcification ( $D$, circles: calcifications are observed as high attenuation on parotid gland).

생길 경우 지방 조직들이 변하고 불균질한 지방 조직의 침착 을 보인다. ${ }^{8,13,14)}$ 자기공명영상 검사는 안전하고 직접적으로 주 침샘을 시각화하여 볼 수 있는 장점이 있지만, 가격이 비싸고 검사 시간이 오래 걸리는 단점이 있다.

본 연구에서는 2016년 ACR/EULAR 분류기준에 따라 쇼 그렌 증후군의 진단기준을 만족시키는 쇼그렌 증후군 그룹 과 그렇지 않은 건조 증상군의 이하선 전산화단층활영 소견 을 비교한 결과, 이하선의 비균질성과 광범위한 비정상적 지 방 조직 침착 소견은 두 군 간에 통계적으로 유의한 차이가 있음을 확인할 수 있었다. 이는 이하선 전산화단층촬영이 쇼 그렌 증후군을 진단하는 데 도움을 줄 수 있음을 시사한다. Baer와 Walitt ${ }^{15)}$ 등 쇼그렌 증후군 환자의 경우 전산화단층촬 영에서 이하선은 다발성 석회화 소견을 보이며, 자기공명영상
상 $\mathrm{T} 1, \mathrm{~T} 2$ 강조 영상에서 비균질성을 보이며, $1 \sim 4 \mathrm{~mm}$ 의 저 신호 강도 또는 고신호 강도 부위(foci)를 보인다고 밝혔다. ${ }^{15)}$

본 연구에서 쇼그렌 증후군 진단에 이하선 전산화단층촬영 검사의 민감도와 특이도는 광범위한 비정상적 지방 조직 침착 소견과 비균질성 소견에서 높게 나타났으며, 이는 2012년 Sun 등 ${ }^{9}$ 의 쇼그렌 증후군 환자에서 이하선 전산화단층촬영에서 보이는 비정상적 지방 조직 침착 비균질성 소견이 높은 민감 도를 보인다는 결과와 일치한다. Sun 등ํ은, 두 명의 평가자가 판단하였을 때 전산화단층촬영 검사상 이하선의 비균질성(민 감도 $88.2 \% / 91.2 \%$; 특이도 $100 \% / 90.9 \%)$. 광범위한 비정상적 지방 조직 침착 소견(민감도 $82.3 \% / 82.3 \%$; 특이도 $100 \%$ / 90.9\%) 항목은 쇼그렌 증후군 진단과 높은 연관관계를 가진 다고 보고하였다. Sun 등'의 연구에서는 광범위한 석회화 소 


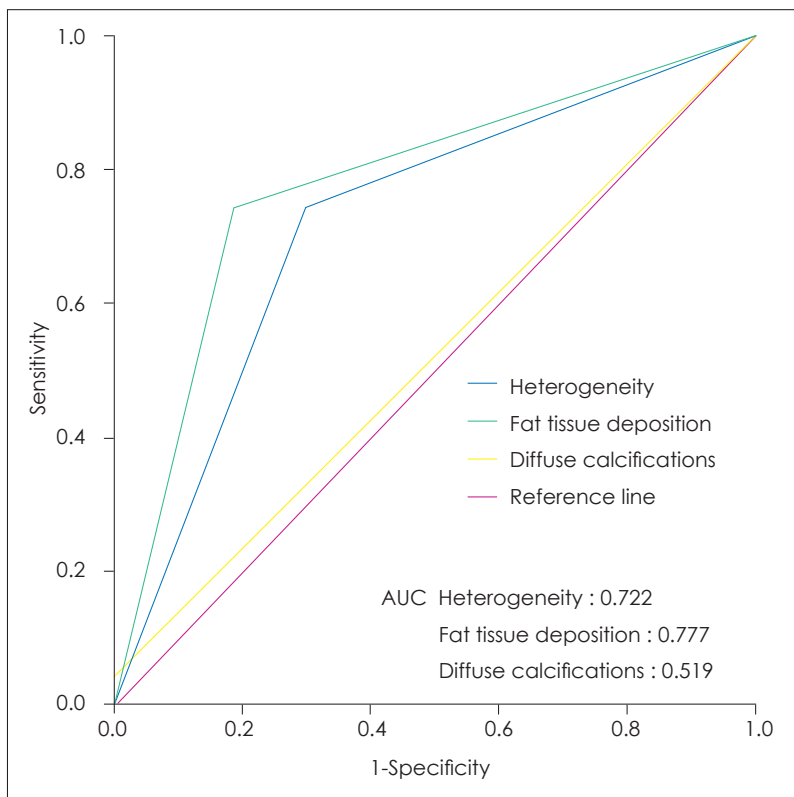

Fig. 2. Receiver operating characteristic curve for quantitative measurements on parotid CT to differentiate Sjögren's syndrome. The areas under the curves, which indicate the diagnostic ability. AUC: area under the curve.

견이 민감도 29.4\%/35.2\%; 특이도 100\%/100\%로 높은 특이도 를 보인다고 보고되었으나, 본 연구에서는 광범위한 석회화 소 견을 보인 환자는 건조 증상군에서는 없었고, 쇼그렌 증후군 군에서 1 명 확인되어 $100 \%$ 민감도를 보였다. 하지만 해당 환 자 수가 적어 통계적 유의성을 확인할 수 없었다. ${ }^{9)}$

쇼그렌 증후군 진단기준의 각 항목과 전산화단층촬영 소 견과의 상관관계에 대한 분석에서는 전산화단층촬영과 임상 증상, 혈청학적 검사의 상관관계를 확인할 수 있었으나, 셔머 검사, 비자극 타액속도 검사, 소타액선 조직 검사에서는 상관 관계를 확인할 수 없었다. 본 연구가 모든 환자에서 모든 검사 를 시행하지 못하였고, 특히 광범위한 석회화 소견을 보인 환 자가 1 명으로 나타났다. 추후 이에 대한 추가적인 연구가 진 행되어 쇼그렌 증후군 진단기준의 각 항목과 전산화단층촬 영 소견의 상관관계를 확인한다면, 쇼그렌 증후군 진단에서 의 전산화단층촬영의 진단적 가치를 더 명확히 할 수 있을 것 으로 생각된다.

쇼그렌 증후군 환자에서는 광범위한 비정상적 지방조직 침 착이 양측 모두 발생할 수 있고, 부분적이거나 불균질하게 나타날 수 있고 질환이 진행함에 따라 이하선의 많은 부분을 차지할 수도 있다. 질환이 진행하면서 균질하게 분포하던 지 방세포가 특정 지역에 쌓이게 되면서 자기공명영상 검사나 전산화단층촬영상 확인되는 것으로 생각된다. ${ }^{8)}$ 악하선은 비 자극 시에 타액의 분비에 주 역할을 하고, 이하선은 자극 시 에 타액의 분비에 주 역할을 하는데, ${ }^{16)}$ 쇼그렌 증후군은 초기
에는 이하선보다는 악하선과 설하선의 기능이 주로 떨어지는 양상을 보이며, 질환이 진행하면서 이하선의 기능도 떨어지 는 양상을 보인다. ${ }^{17)}$ 본 연구에서는 악하선을 연구하지는 않 았지만, 향후 쇼그렌 증후군과 전산화단층촬영에서 악하선 소견에 대한 연구가 이루어진다면 진단적 가치를 높일 수 있 을 뿐만 아니라 쇼그렌 증후군의 병기에 대한 연구도 이루어 질 수 있을 것으로 생각된다.

$\mathrm{ROC}$ 분석에서는 이하선 전산화단층촬영의 진단적 신뢰 도는 비정상적 지방 조직 침착 소견이 가장 높은 것으로 나 타났으며, 다음으로 이하선의 비균질성 소견도 쇼그렌 증후 군에 높은 진단적 가치가 있는 것으로 판단할 수 있다.

본 연구의 한계점으로는 1 명의 영상의학과 전문의가 이하 선 전산화단층촬영의 판독을 하였기 때문에 여러 명의 검사 자 간 비교를 하지 못한 점이 있을 수 있다. 또한 후향적 연구 로 시행하였기 때문에 모든 환자에서 2016년 ACR/EULAR 분류기준의 5 가지 검사 항목 모두를 시행하지 못한 점이 한 계로 작용한다. 그리고 전산화단층촬영의 경우 방사선 조사 의 위험성으로 인해 임상적으로 초기 검사로 이용하기 어려 운 한계가 있다. 마지막으로 전체 환자 대상군을 건조 증상 으로 내원한 환자로 하였기 때문에, 명확한 무증상의 대조군 과의 비교가 없었던 것도 본 연구의 한계점이다.

혈청학적 검사나 소타액선의 조직 검사 소견 없이 전산화 단층촬영에서 이하선의 비균질성과 광범위한 비정상적 지방 조직 침착 소견만 보인다고 해서 쇼그렌 증후군을 진단할 수 있는 것은 아니다. 하지만, 이하선 전산화단층촬영은 쇼그렌 증후군의 진단에 도움을 줄 수 있으며, 이하선의 비균질성 소견과 비정상적 지방 조직 침착 소견은 높은 민감도와 특이 도를 보이고, 진단적 가치가 높아 쇼그렌 증후군 환자를 진 단함에 있어 의미 있는 정보를 제공할 수 있다.

\section{Supplementary Materials}

The Data Supplement is available with this article at https://doi. org/10.3342/kjorl-hns.2019.00367.

\section{Acknowledgments}

This research was supported by Inha University Research Grant.

\section{Author Contribution}

Conceptualization: Ji Won Kim. Data curation: Soo Hyun Joo. Formal analysis: Hyung Sun Hong. Investigation: Hyung Sun Hong. Methodology: Young-Hye Kang. Project administration: Young-Mo Kim. Resources: Mie Jin Lim. Supervision: Jeong-Seok Choi. Validation: Ji Won Kim. Visualization: Hong-Ju Kim. Writing —original draft: Hyung Sun Hong. Writing — review \& editing: Ji Won Kim.

\section{ORCID}

Ji Won Kim

https://orcid.org/0000-0003-1587-9671 


\section{REFERENCES}

1) Vitali C, Bombardieri S, Jonsson R, Moutsopoulos HM, Alexander EL, Carsons SE, et al. Classification criteria for Sjögren's syndrome: A revised version of the European criteria proposed by the American-European consensus group. Ann Rheum Dis 2002; 61(6):554-8.

2) Theander E, Henriksson G, Ljungberg O, Mandl T, Manthorpe R, Jacobsson LT. Lymphoma and other malignancies in primary Sjögren's syndrome: A cohort study on cancer incidence and lymphoma predictors. Ann Rheum Dis 2006;65(6):796-803.

3) Shiboski SC, Shiboski CH, Criswell L, Baer A, Challacombe S, Lanfranchi $\mathrm{H}$, et al. American College of Rheumatology classification criteria for Sjögren's syndrome: A data-driven, expert consensus approach in the Sjögren's International Collaborative Clinical Alliance cohort. Arthritis Care Res (Hoboken) 2012;64(4):475-87.

4) Shiboski CH, Shiboski SC, Seror R, Criswell LA, Labetoulle M, Lietman TM, et al. 2016 American College of Rheumatology/ European League Against Rheumatism classification criteria for primary Sjögren's syndrome: A consensus and data-driven methodology involving three international patient cohorts. Ann Rheum Dis 2017;76(1):9-16.

5) Goules AV, Tzioufas AG. Imaging: Diagnostic value of ultrasonography in Sjögren's syndrome. Nat Rev Rheumatol 2014;10(8):450-2

6) Cornec D, Jousse-Joulin S, Saraux A, Devauchelle-Pensec V. Salivary gland ultrasound to diagnose Sjögren's syndrome: A claim to standardize the procedure. Rheumatology (Oxford) 2015;54(1): 199-200.

7) Kim JW, Lee H, Park SH, Kim SK, Choe JY, Kim JK. Salivary gland ultrasonography findings are associated with clinical, histological, and serologic features of Sjögren's syndrome. Scand J Rheumatol 2018;47(4):303-10.

8) Izumi M, Eguchi K, Nakamura H, Nagataki S, Nakamura T.
Premature fat deposition in the salivary glands associated with Sjögren syndrome: MR and CT evidence. AJNR Am J Neuroradiol 1997:18(5):951-8

9) Sun Z, Zhang Z, Fu K, Zhao Y, Liu D, Ma X. Diagnostic accuracy of parotid CT for identifying Sjögren's syndrome. Eur J Radiol 2012;81(10):2702-9.

10) Villa A, Wolff A, Narayana N, Dawes C, Aframian DJ, Lynge Pedersen AM, et al. World Workshop on Oral Medicine VI: A systematic review of medication-induced salivary gland dysfunction. Oral Dis 2016;22(5):365-82.

11) Daniels TE, Benn DK. Is sialography effective in diagnosing the salivary component of Sjögren's syndrome? Adv Dent Res 1996;10(1):25-8.

12) Kalk WW, Vissink A, Spijkervet FK, Bootsma H, Kallenberg CG, Roodenburg JL. Parotid sialography for diagnosing Sjögren syndrome. Oral Surg Oral Med Oral Pathol Oral Radiol Endod 2002;94(1):131-7.

13) Izumi $M$, Eguchi $K$, Ohki $M$, Uetani $M$, Hayashi $K$, Kita $M$, et al. MR imaging of the parotid gland in Sjögren's syndrome: A proposal for new diagnostic criteria. AJR Am J Roentgenol 1996;166(6):1483-7.

14) Takagi Y, Sumi M, Sumi T, Ichikawa $Y$, Nakamura T. MR microscopy of the parotid glands in patients with Sjogren's syndrome: Quantitative MR diagnostic criteria. AJNR Am J Neuroradiol 2005;26(5):1207-14.

15) Baer AN, Walitt B. Sjögren syndrome and other causes of Sicca in older adults. Clin Geriatr Med 2017;33(1):87-103.

16) Navazesh M, Kumar SK; University of Southern California School of Dentist ry. Measur ing salivary f low: Challenges and opportunities. J Am Dent Assoc 2008;139 Suppl:35S-40S.

17) Pijpe J, Kalk WW, Bootsma H, Spijkervet FK, Kallenberg CG, Vissink A. Progression of salivary gland dysfunction in patients with Sjogren's syndrome. Ann Rheum Dis 2007;66(1):107-12. 
Supplementary Table 1. American College of Rheumatology/European League Against Rheumatism classification criteria for primary SS: the classification of primary SS applies to any individual who meets the inclusion criteria, ${ }^{*}$ does not have any of the conditions listed as exclusion criteria, ${ }^{\dagger}$ and has a score of $\geq 4$ when the weights from the five criteria items below are summed

\begin{tabular}{lc}
\hline \multicolumn{1}{c}{ Imaging } & Score \\
\hline Labial salivary gland with focal lymphocytic sialadenitis and focus score of $\geq 1$ foci/4 $\mathrm{mm}^{2} \ddagger$ & 3 \\
Anti-SSA/Ro-positive & 3 \\
Ocular staining score $\geq 5$ (or van Bijsterveld score $\geq 4$ ) in at least one eye $\$ \|$ & 1 \\
Schimer's test $\leq 5 \mathrm{~mm} / 5 \mathrm{~min}$ in at least one eye & 1 \\
Unstimulated whole saliva flow rate $\leq 0.1 \mathrm{~mL} / \mathrm{min} \$ \pi$ & 1
\end{tabular}

*These inclusion criteria are applicable to any patient with at least one symptom of ocular or oral dryness, defined as a positive response to at least one of the following questions: (1) Have you had daily, persistent, troublesome dry eyes for more than 3 months? (2) Do you have a recurrent sensation of sand or gravel in the eyes? (3) Do you use tear substitutes more than three times a day? (4) Have you had a daily feeling of dry mouth for more than 3 months? (5) Do you frequently drink liquids to aid in swallowing dry food? or in whom there is suspicion of SS from the European League Against Rheumatism SS Disease Activity Index questionnaire (at least one domain with a positive item). tExclusion criteria include prior diagnosis of any of the following conditions, which would exclude diagnosis of SS and participation in SS studies or therapeutic trials because of overlapping clinical features or interference with criteria tests: (1) history of head and neck radiation treatment, (2) active hepatitis $C$ infection (with confirmation by polymerase chain reaction), (3) acquired immunodeficiency disease, (4) sarcoidosis, (5) amyloidosis, (6) graftversus-host disease, and (7) IgG4-related disease. 佗e histopathologic examination should be performed by a pathologist with expertise in the diagnosis of focal lymphocytic sialadenitis and focus score count, using the protocol described by Daniels, et al." spatients who are normally taking anticholinergic drugs should be evaluated for objective signs of salivary hypofunction and ocular dryness after a sufficient interval without these medications in order for these components to be a valid measure of oral and

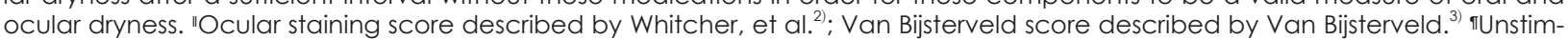
ulated whole saliva flow rate measurement described by Navazesh and Kumar. ${ }^{4)}$ SS: Sjögren's syndrome

\section{REFERENCES}

1) Daniels TE, Cox D, Shiboski CH, Schiødt M, Wu A, Lanfranchi H, et al. Associations between salivary gland histopathologic diagnoses and phenotypic features of Sjögren's syndrome among 1,726 registry participants. Arthritis Rheum 2011;63(7):2021-30.

2) Whitcher JP, Shiboski CH, Shiboski SC, Heidenreich AM, Kitagawa K, Zhang S, et al. A simplified quantitative method for assessing keratoconjunctivitis sicca from the Sjögren's Syndrome International Registry. Am J Ophthalmol 2010;149(3):405-15.

3) Van Bijsterveld OP. Diagnostic tests in the Sicca syndrome. Arch Ophthalmol 1969;82(1):10-4.

4) Navazesh M, Kumar SK; University of Southern California School of Dentist ry. Measur ing salivary f low: Challenges and opportunities. J Am Dent Assoc 2008;139 Suppl:35S-40S. 